\title{
- A Morphological Study of Suprascapular Notch and Incidence of Ossification of Superior Transverse Scapular Ligament in South Indian Dry Scapulae
}

\section{S. Vedha ${ }^{1}$, K. Vidulatha ${ }^{2}$}

'Assistant Professor, Velammal Medical College, Madurai, Tamilnadu, India; 'Assistant professor, Govt sivagangai Medical College, Sivagangai, Tamilnadu, India.

\section{ABSTRACT}

Introduction: The suprascapular notch is converted into suprascapular foramen by bridging of superior transverse scapular ligament (STSL) on its edges. The structures related to STSL are the suprascapular vessel which passes above and suprascapular nerve which passes below the ligament to reach the supraspinous fossa. The anterior coracoscapular ligament (ACSL) is present below the suprascapular ligament. Ossification of both STSL and ACSL leads to formation of double suprascapular foramen.

Aim: The aim of the present study is to know the incidence of suprascapular foramen and prevalence of different types of suprascapular notch in south Indian dry scapula.

Method and Result: 250 scapulae were examined in the present study. Out of which, 23 (9.2\%) showed complete ossification and $13(5.2 \%)$ showed partial ossification of STSL. Presence of both complete and partial foramen was observed in one of the right sided scapula.

Conclusion: The knowledge of variation in shape of suprascapular notch and ossification of both STSL and ACSL is of great concern for anatomist, neurosurgeon, radiologist and orthopaedician to understand the cause of suprascapular nerve entrapment syndrome and for better management of those cases.

Key Words: Suprascapular notch (SSN), Superior transverse scapular ligament (STSL), Anterior coracoscapular ligament (ACSL), Suprascapular nerve (SN), Suprascapular nerve entrapment syndrome

\section{INTRODUCTION}

The suprascapular notch is a depression on the superior border of the scapula just medial to the root of coracoid process. The notch is bridged by the superior transverse scapular ligament. Sometimes the suprascapular ligament is ossified to form a foramen that transmits the suprascapular nerve. The suprascapular nerve is the largest branch of upper trunk of brachial plexuses. It supplies both supraspinatus and infraspinatus muscles and gives articular branches to the shoulder and acromioclavicular joints ${ }^{1}$.

Approximately $1-2 \%$ of all shoulder pain is caused by the suprascapular nerve entrapment syndrome ${ }^{2}$. Kopell and
Thompson was the first to describe the suprascapular nerve entrapment in $1959^{3}$. Many authors have identified that the morphological variation of the suprascapular notch and the ossification of the STSL is the cause of suprascapular nerve entrapment syndrome $e^{4,5,6,7}$. The ossification of the ligament is either partial or complete ${ }^{4}$. The size and shape of the notch may be a factor in suprascapular nerve entrapment because narrow suprascapular notch have been found in patients with this syndrome $e^{2,8,9,10,11,12}$. It is essential for clinical practice because various techniques are associated with the athroscopic decompression of the nerve $\mathrm{e}^{13,14,15}$.

\section{Corresponding Author:}

S. Vedha, Assistant Professor, Velammal Medical College, Madurai, Tamilnadu, India. Mob: 9976029696; E-mail: drvedhas@gmail.com

ISSN: 2231-2196 (Print)

Received: 15.05 .2017
ISSN: 0975-5241 (Online)

Revised: 08.06.2017
DOI: 10.7324/IJCRR.2017.9138

Accepted: 20.06 .2017 


\section{AIM OF THE STUDY}

To study the incidence of completely ossified superior transverse scapular ligament forming suprascapular foramen in dry scapulae of Indian population.

1. To identify the different shapes of suprascapular notch.

2. To compare our results with previous authors.

\section{MATERIAL AND METHODS}

A total of 250 human scapulae obtained from the Department of Anatomy, Velammal medical college, Madurai and Govt. Sivagangai medical college, Sivagangai were analysed. Out of this, number of scapulae with completely ossified superior transverse scapular ligament and different shapes of suprascapular notch were identified, photographed and documented. The result of the present study is compared with the results of previous authors in Indian populations.

\section{RESULTS}

Out of 250 scapulae, $23(9.2 \%)$ were identified to have complete ossification and $13(5.2 \%)$ were identified to have partial ossification of superior transverse scapular ligament. One of the scapulae showed both complete and partial foramen in the same scapula was noted (Table 2). Six different shapes of the suprascapular notch were also observed (Table 1).

\section{DISCUSSION}

The incidence of complete ossification of suprascapular ligament according to Udayasree ${ }^{16}$, Usha ${ }^{17}$ were $9.5 \%$ and $10 \%$ respectively. Whereas Jawed ${ }^{18}$ and Mistry ${ }^{19}$ recorded higher incidence and shiksha ${ }^{20}$, polguj ${ }^{21}$, and Soni ${ }^{10}$ recorded a lower incidence. Hence the present study is in accordance with the study done by Udayasree and Usha.

According to Rengachary ${ }^{22}$, Muralidhar ${ }^{23}$ and Usha kan$\operatorname{nan}^{17}$ the incidences of partial ossification of suprascapular ligament were $6 \%, 5.76 \%$ and $4 \%$ respectively. Hence the present study is in conformity to the above mentioned studies. However Soni ${ }^{10}$ in his study didn't encounter a single scapula with partial ossification.

Double suprascapular foramen was reported only by four authors in the past. Hrdlica ${ }^{24}$ was the first to report this type of variation in 1942 followed by Wang ${ }^{25}$ in 2011, Polguj ${ }^{26}$ in 2012 and Serghei $^{27}$ in 2016. In addition, Polguj proposed four hypothesis for formation of double foramen.

Hypothesis 1: ossification of superior transverse scapular ligament, anterior coracoscapular ligament
Hypothesis 2: ossification of bifid superior transverse scapular ligament

Hypothesis 3: partial ossification of trifid superior transverse scapular ligament

Hypothesis 4: ossification of bifid anterior coracoscapular ligament

Out of these four hypothesis, first one was highlighted to be the cause for double foramen by Polguj in his study ${ }^{26}$. This type of variation may involve in compression of both nerve and vessels. In the present study, one scapula $(0.4 \%)$ with double foramen was noted. But one foramen was partially ossified and the other was complete. Thus in the present study complete ossification of anterior coracoscapular ligament and partial ossification of superior transverse scapular ligament was noted.

Rengachary ${ }^{22}$ in his study of 211 cadaveric adult scapulae, had classified 6 basic type of suprascapular notch

Type 1: absence of notch

Type 2: V shaped notch

Type 3: U shaped notch

Type 4: small V shaped notch

Type 5: U shaped notch with partial ossification of suprascapular ligament

Type 6: complete ossification of suprascapular ligament

In the present study, all the above types of notch had been encountered expect type 4 . Instead J shaped notch were observed in $13(5.2 \%)$ scapulae.

The most common type of notch observed and in the present study was U shaped (53.2\%) which was in accordance with the studies of previous authors. But in the present study two types of $U$ shaped notch were observed that is a deep $\mathrm{U}$ which accounted for $37.2 \%$ and a shallow $U$ for $16 \%$ of scapulae.

The incidence of absence of suprascapular notch in the present study was $21.2 \%$ which was in accordance with the studies conducted by Iqbal2 ${ }^{28}(18 \%)$, Muralidhar ${ }^{23}(21.15 \%)$ and Usha kannan ${ }^{17}(20 \%)$.

However, in the present study absence of the notch was observed and recorded on both sides which were similar to the study conducted by Raj kishore ${ }^{29}$. He examined 112 scapulae and found absence of notch in $8.93 \%$ and $10.71 \%$ on right and left sides respectively. In the present study absence of notch was observed in $8 \%$ and $13.2 \%$ on right and left sides respectively.

Hence the present study is in accordance with the previous studies done by Muralidhar and Usha kannan. 


\section{CONCLUSIONS}

Since the suprascapular notch is the most common site of both injury and compression of the suprascapular nerve, a thorough knowledge of this region is essential. This study would help the clinicians for better management of suprascapular nerve entrapment syndrome.

\section{ACKNOWLEDGEMENTS}

We would like to acknowledge all the faculty members and technical staff in our department for their advice and assistance. We also acknowledge the immense help received from the scholars whose articles are cited and included in references of this manuscript and are grateful to authors / editors / publishers of all those articles, journals and books from where the literature for this article has been reviewed and discussed.

\section{REFERENCES}

1. Standring SM, Ellis H, Healy JC, Johnson D, Williams A (2005) gray's anatomy. 39th ed. Churchill-livingstone, Edinburgh.

2. M. Polguj, K.S. Jędrzejewski, M. Podgórski, M. Topo (2011) correlation between morphometry of the suprascapular notch and anthropometric measurements of the scapula. Folia morphol. Vol. 70, no. 2, pp. 109-115.

3. Kopell HP, Thompson Wal (1959) pain and the frozen shoulder. Surg gynecol obstet, 109: 92-96.

4. Ticker JB, Djurasovic M, Strauch RJ, April EW, Pollock RG, Flatow EL, et al. The incidence of ganglion cysts and other variations in anatomy along the course of the suprascapular nerve. $\mathrm{J}$ shoulder elbow surg.1998;7(5):472-8.

5. Osuagwu FC, Imosemi IO, Shokunbi MT complete ossification of the superior transverse scapular ligament in a nigerian male adult. Int j morphol. 2005;23(2):121-2.

6. Callahan JD, Scully TB, Shapiro SA, Worth RM. Suprascapular nerve entrapment: a series of 27 cases. J neurosurg. 1991;74:8936.

7. Bayramoglu A, Demiryürek D, Tüccar E. Variations in anatomy at the suprascapular notch possibly causing suprascapular nerve entrapment: an anatomical study. Knee surg sports traumatol arthrosc. 2003;11:393-8.

8. Jadhav SD, Patil RJ, Roy PP, Ambali MP, Doshi MA, Desai RR. Supra scapular foramen in indian dry scapulae.njca. 2012; 1(3): 133-135.

9. Shane tubbs, Carl Nechtman, Anthony V. D'antoni, Mohammadali M.Shoja Martin M. Mortazavi, Marios Loukas, Curtis J. Rozzelle, and Robert J. Spinner ossification of the suprascapular ligament: a risk factor for suprascapular nerve compression? Int J shoulder surg. 2013 jan-mar; 7(1): 19-22.

10. G. Soni, V.S. Malik, L.Shukla, S. Chabbra, N. Gaur: Morphometric analysis of the suprascapular notch. The internet journal of biological anthropology. 2012 volume 5 numberi. doi: $10.5580 / 2 b 19$

11. Khan, M.A. complete ossification of the suprascapular transverse ligament in an male adult. Int. J. Morphol., 24(2):195-196. 2006

12. Vyas, Kintu K.; Rajput, Hina B.; Zanzrukiya, Kalpesh M.; Sut- tarwala, Ila; Sarvaiya, Bharat J.; Shroff, Bhavesh D. An osseous study of suprascapular notch and various dimentions of safe zone to prevent suprascapular nerve injury. Indian journal of applied basic medical sciences;jan2013, vol. 15 issue 20, p27

13. Barwood SA, Burkhart SS, LO IK (2007) arthroscopic suprascapular nerve release at the suprascapular notch in a cadaveric model: an anatomic approach. Arthroscopy, 23: 221-225.

14. Bhatia DN, De Beer JF, Van Rooyen KS, Du Toit DF (2006) arthroscopic suprascapular nerve decompression at the suprascapular notch. Arthroscopy, 22: 1009-1013.

15. Lafosse L, Tomasi A, Corbett S, Baier G, Willems K, Gobezie R (2007) arthroscopic release of suprascapular nerve entrapment at the suprascapular notch: technique and preliminary results. Arthroscopy, 23: 34-42.

16. Udayasree L, Siva Prasad G V, Lakshmi V V V. Study of anatomical variations in the shape of suprascapular notch in dried human scapulae and its clinical significance. Journal of evolution of medical and dental sciences 2014; 3 (22): 6053-6057, doi: $10.14260 /$ jemds/2014/2704

17. Kannan U, N.S Kannan, Anbalagan J, Rao S. Morphometric Study of Suprascapular Notch in Indian Dry Scapulae with Specific Reference to the Incidence of Completely Ossified Superior Transverse Scapular Ligament.JCDR.2014;8(3):7-10.

18. Akhtar J, Madhukar P, Fatima N, Kumar A, Kumar B, Sinha R, Kumar V. Ossification of transverse scapular ligament in north indian population. JEMDS, 3(63):13884-92. 2014

19. Mistry P, Chuhan K, Mehta C, Patil D, Bansal M, Suthar K. A study of incidence of ossification of superior transverse scapular ligament of scapula and its clinical implications. Int $\mathrm{j}$ of basic and applied medical sciences. 2013; 3 (2): 41-45.

20. Jangde S, Arya R, Paikra S, Basan K. Bony suprascapular foramen, a potential site for suprascapular nerve entrapment: a morphological study on dried human scapulae international journal of anatomy and research, int j anat res 2015, vol 3(3):1316-20. Issn 2321- 4287

21. Polguj M, Jędrzejewski K, Majos A, Topol M. Variations of bifid superior transverse scapular ligament as a possible factor of suprascapular entrapment: a anatomical study. International orthopaedics 2012; 36: 2095-2100

22. Rengachary SS, Burr D, Lucas S, Hassanein KM, Mohn MP, Matzke H (1979) suprascapular entrapment neuropathy: a clinical, anatomical, and comparative. Study part 2: anatomical study. Neurosurgery, 5(4): 447-451

23. Muralidhar Reddy Sangam, Sattiraju Sri Sarada Devi, Karumanchi Krupadanam, and Kolla Anasuya. A study on the morphology of the suprascapular notch and its distance from the glenoid cavity. J Clin Diagn Res. 2013 February; 7(2): 189-192.

24. Hrdicka A. The adult scapula: additional observation and measurement. Am J Phys Anthropol.1942;29:363-415.

25. Wang HJ, Chen C, Wu LP, Pan CQ, Zhang WJ, Li YK. Variable morphology of suprascapular notch: an investigation and quantitative measurement in Chinese population. Clin Anat.2011;24(1):47-55.

26. Polguj M, Podgorski M, Jedrzejewski K, Topol M. The double suprascapular foramen: unique anatomical variation and the new hypothesis of its formation. Skeletal Radiol.2012;41:1631-36.

27. Covantev S, Belic O, Mazuruc N. Double suprascapular foramen: a rare scapular notch variation. Russian open Medical Journal.2016;5(3):1-3.

28. Iqbal K, Iqbal K, Khan S G. Anatomical variations in shape of suprascapular notch of scapula. J.morphol sci. 2010; 27(1): 1-2.

29. Raj Kishore Mahato, Parineeta Suman. "Complete Absence of the Suprascapular Notch: A Risk Factor for Suprascapular Nerve Entrapment Neuropathy". Journal of Evolution of Medical and Dental Sciences 2013; 12( 25): 4542-4547. 
30. Agrawal D, Singh B, Agrawal GA. Human Scapulae: Supra Scapular Notch, Morphometry and Variations. Indian Journal of Clinical Anatomy and Physiology.2014;1:1-7.

Table 1: Shows the incidence of different shapes of the suprascapular notch on both sides.

\begin{tabular}{|c|c|c|c|c|c|c|}
\hline \multirow{2}{*}{ S. No. } & \multirow{2}{*}{ Shape of the notch } & \multicolumn{2}{|c|}{ Right } & \multicolumn{2}{|c|}{ Left } & \multirow{2}{*}{$\begin{array}{l}\text { Total } \\
\text { n (\%) }\end{array}$} \\
\hline & & No & $\%$ & No & $\%$ & \\
\hline & Deep U shaped & 50 & 20 & 43 & 17.2 & $93(37.2)$ \\
\hline & Shallow U shaped & 17 & 6.8 & 23 & 9.2 & $40(16)$ \\
\hline & V shaped & 9 & 3.6 & 5 & 2 & $14(5.6)$ \\
\hline & J shaped & 7 & 2.8 & 6 & 2.4 & $13(5.2)$ \\
\hline & No notch & 20 & 8 & 33 & 13.2 & $53(21.2)$ \\
\hline
\end{tabular}

Table 2: Shows incidence of both partial and complete ossification of suprascapular ligament on both sides.

\begin{tabular}{|c|c|c|c|c|c|c|}
\hline \multirow{2}{*}{ S. No. } & \multirow{2}{*}{ Presence of foramen } & \multicolumn{2}{|c|}{ Right } & \multicolumn{2}{|c|}{ Left } & \multirow{2}{*}{$\begin{array}{l}\text { Total } \\
\text { n (\%) }\end{array}$} \\
\hline & & No & $\%$ & No & $\%$ & \\
\hline & Partial foramen & 6 & 2.4 & 7 & 2.8 & $13(5.2)$ \\
\hline & Complete foramen & 12 & 4.8 & 11 & $4 \cdot 4$ & $23(9.2)$ \\
\hline & Complete + partial foramen & 1 & 0.4 & - & - & $1(0.4)$ \\
\hline
\end{tabular}

Table 3: Shows the comparative statement of different types of notch studied by different authors.

\begin{tabular}{|c|c|c|c|c|c|c|c|c|c|}
\hline $\begin{array}{l}\text { S. } \\
\text { No. }\end{array}$ & Author with year & $\begin{array}{c}\text { U } \\
\text { shaped } \\
\text { notch }\end{array}$ & $\begin{array}{c}\text { V } \\
\text { shaped } \\
\text { notch }\end{array}$ & $\begin{array}{c}\text { J } \\
\text { shaped } \\
\text { notch }\end{array}$ & $\begin{array}{c}\text { Ill- } \\
\text { defined } \\
\text { notch }\end{array}$ & No notch & $\begin{array}{l}\text { Partial } \\
\text { foramen }\end{array}$ & $\begin{array}{l}\text { Complete } \\
\text { foramen }\end{array}$ & $\begin{array}{c}\text { Complete }+ \\
\text { Partial foramen }\end{array}$ \\
\hline 1 & Soni $^{10}(2012)$ & $58 \%$ & $7 \%$ & 27 & - & $2 \%$ & $11 \%$ & $3 \%$ & - \\
\hline 2 & $\operatorname{Iqbal}^{24}(2010)$ & $13.2 \%$ & $20 \%$ & $22 \%$ & $26.8 \%$ & $18 \%$ & - & - & - \\
\hline 3 & Rengachary $^{22}(1979)$ & $48 \%$ & $31 \%$ & - & - & $8 \%$ & $6 \%$ & $4 \%$ & - \\
\hline 4 & Dushyant $^{30}(2014)$ & $45 \%$ & $23.54 \%$ & - & $12.28 \%$ & $1.36 \%$ & - & - & - \\
\hline 5 & $\operatorname{Muralidhar}^{23}(2013)$ & $59.61 \%$ & $8.65 \%$ & - & - & $21.15 \%$ & $5 \cdot 76 \%$ & $1.92 \%$ & - \\
\hline 6 & Usha kannan ${ }^{17}(2014)$ & $52 \%$ & $14 \%$ & - & - & $20 \%$ & $4 \%$ & $10 \%$ & - \\
\hline 7 & $\begin{array}{l}\text { In present study } \\
(2017)\end{array}$ & $53.2 \%$ & $5.6 \%$ & $5.2 \%$ & & $21.2 \%$ & $5.2 \%$ & $9.2 \%$ & $0.4 \%$ \\
\hline
\end{tabular}




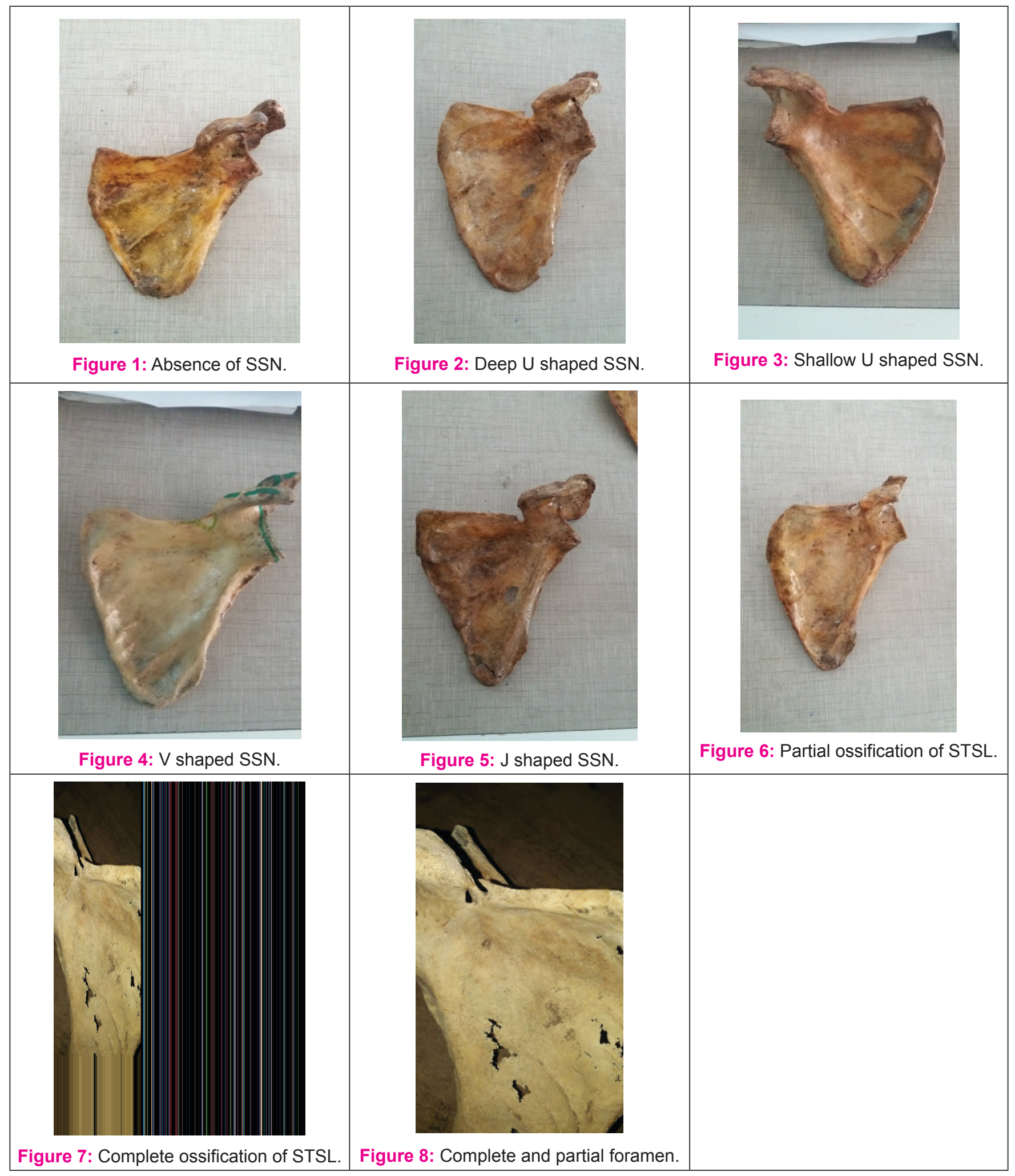

